\title{
An Economic Analysis of Bidi Tobacco Cultivation in Belgaum District, Karnataka
}

\author{
T. Rajesh ${ }^{1 *}$ and G. S. Ananth ${ }^{2}$ \\ ${ }^{1}$ Division of Forecasting and Agricultural Systems Modelling, ICAR-Indian Agricultural \\ Statistics Research Institute, New Delhi, India \\ ${ }^{2}$ Department of Agricultural Economics, College of Agriculture, University of Agricultural \\ Sciences, GKVK, Bangalore, India \\ *Corresponding author
}

\section{A B S T R A C T}

\section{Keywords}

Net return, Production function analysis, Bidi tobacco, Resource use efficiency

Article Info

Accepted:

07 November 2020

Available Online:

10 December 2020
The present study was conducted to examine the production aspects of bidi tobacco cultivation in Belgaum district of Karnataka state. The required information was collected from 40 sole tobacco farmers (Cropping System-I) and 40 famers growing tobacco as intercrop with sorghum (Cropping System-II) from the study area. The results indicated that per acre net return realized under CS-II was higher (Rs. 37,549) compared to CS-I (Rs. 28,480). Labour cost constitutes the major share in total cost of cultivation of tobacco, which was followed by the marketing cost. Production function analysis revealed that in CS-I, gross income was significantly and positively influenced by fertilizer, human labour, animal labour, machinery hours and seedling cost, where as in case of CS-II, fertilizer, animal labour and human labour were found to be statistically significant. In both CS-I and CS-II situations, fertilizer, FYM and GM, human labour and bullock labour were not used optimally, suggesting that there was still scope for increasing use of these resources to get increased returns. It can be inferred that, the efforts should be made to encourage farmers to adopt intercropping system to enhance their income which will also avoid the risk of crop failure.

\section{Introduction}

Tobacco also called as "Golden Leaf" is one of the important commercial crops of India and being so, it is vital in the Indian economy. It occupies the third position in the world with an annual production of about 750 Million Kgs. Brazil and China are the leading producers and exporters followed by India.
Tobacco and tobacco products earn approximately Rs.22737 Crores to the national exchequer by way of excise revenue, and approx.Rs.5870 Crores by way of foreign exchange for the year 2019-20 (GOI, 2019a).

Although the cultivation of Tobacco is restricted to 0.24 per cent of the total cultivated area (GOI, 2019b), it provides 
employment to a large number of people on the one hand, it makes significant contribution to National Exchequer by way of excise revenue and foreign exchange earnings to the another side (Doshi, 1985). Tobacco is a labour-intensive crop in India. Growing, harvesting and processing of tobacco represent the means of livelihood of a large number of agricultural labourers. About 20 million farm laborers were employed under tobacco industry across India as of January 2020. The tobacco industry provides direct and indirect employment to approximately 45.7 million people in the country who are engaged in the various processes of tobacco cultivation, curing, re-drying, packaging, distribution, manufacturing, export and retailing activities.

The tobacco Industry in India contributes in a unique manner to several important facets of the Indian economy, covering revenue, export, employment, and GDP growth. The cigarette industry in India and abroad, represents a big revenue opportunity for the economy. The Bidi industry is one of the foremost cottage industries in the country. Around 37 per cent of the tobacco produced in India goes into Bidi making as per an Indian Market Research Bureau (IMRB) report in 1996. The social significance of the Bidi Industry is that it generates more employment compared to the cigarette industry. Keeping in view of the above issues attempts is made to study the economics of production of bidi tobacco crop in Belgaum district of Karnataka.

\section{Materials and Methods}

Karnataka being the second largest state in terms of area under tobacco cultivation in India, has been purposively selected for the study purpose. The sampling design adopted for the investigation was stratified random sampling of tobacco growers. In Karnataka,
Belgaum district alone contributes 87 per cent of the total production of tobacco. Chikodi taluka alone contributes 68.9 per cent of the total area under bidi tobacco in Belgaum district (Government of Karnataka, 2009-10). Nipani area is the major bidi producing area and has wholesale market in Chikodi. Hence, Chikodi taluka of Belgaum district was selected purposively for the study. The agricultural year 2010-11 was considered for the data relating to the size of holding, general information of farmers, cropping pattern, and land under bidi tobacco cultivation, resource use pattern and constraints in production were collected from the sample farmers.

Production function is the convenient economic frame work for testing the equality of parameters governing input-output relationship and for decomposing the total change in output. The general form of the function is $y=a x_{i}{ }^{b i}$ where, ' $y$ ' is the output, ' $x_{i}{ }^{\prime}$ is the variable resource, ' $a$ ' is a constant and ' $b_{i}$ ' estimates the extent of relationship between $\mathrm{x}_{\mathrm{i}}$ and $\mathrm{y}$ and when $\mathrm{x}_{\mathrm{i}}$ is at different magnitudes. The ' $b$ ' coefficient also represents the elasticity of production in Cobb-Douglas production function analysis (Rajesh and Ananth, 2012).

This type of function allows for either constant or increasing or decreasing returns to scale. It does not allow for total product curve embracing all the three simultaneously. Functions of the following form were fitted for two cropping Systems i.e. Sole tobacco (CS-I) and Tobacco as inter crop with Sorghum (CS-II).

$\mathrm{Y}=\mathrm{ax}_{1}{ }^{\mathrm{b} 1} \mathrm{x}_{2}{ }^{\mathrm{b} 2} \mathrm{x}_{3}{ }^{\mathrm{b} 3} \ldots \ldots \ldots \ldots \ldots \mathrm{x}_{\mathrm{n}}{ }^{\mathrm{bn}}$

On linearization, above equation becomes

$\log Y=\log a+b_{1} \log x_{1}+b_{2} \log x_{2}+b_{3} \log x_{3}+$ $+b_{n} \log x_{n}$ 
Production function employed for cropping system as a whole is given as

$\log Y=\log a+b_{1} \log x_{1}+b_{2} \log x_{2}+b_{3} \log x_{3}$ $+b_{4} \log x_{4}+b_{5} \log x_{5}+b_{6} \log x_{6}+b_{7} \log x_{7}+e$.

Where,

$\mathrm{Y}=$ Gross returns in Rs/ac.

$\mathrm{a}=$ Intercept

$\mathrm{x}_{1}=$ Fertilizer Rs/ac.

$\mathrm{x}_{2}=$ Manure Rs/ac.

$\mathrm{x}_{3}=$ Human labour Rs/ac.

$\mathrm{x}_{4}=$ Animal labour Rs/ac.

$\mathrm{X}_{5}=$ Machinery hours Rs/ac.

$\mathrm{x}_{6}=$ Seedling cost Rs/ac.

$\mathrm{x}_{7}=$ Plant protection chemicals Rs/ac.

$\sum$ bi $=$ return to scale $(i=1$ to 7$)$

$\mathrm{e}=$ Error term

\section{Results and Discussion}

\section{Cost of cultivation of tobacco crop}

It could be noticed from the Table 1 that among the two categories of tobacco cultivators, per acre total costs of tobacco cultivation was higher at Rs. 34,431.72for cultivation of tobacco as inter crop compared to the sole crop of tobacco (Rs. 30,423.85). It may be due to that, they are not incurring additional variable cost on Sorghum. Total variable costs accounted for more than 93 per cent in both the categories and fixed cost accounted for less than 7 per cent. The variable cost per acre was Rs. 28,340 and Rs. 32,593 for Cropping System-I (CS-I) and Cropping System-II (CS-II), respectively.

Labour cost was the major cost among both the systems of $15,475.5(50.87 \%)$ and Rs. $18,481.75(53.21 \%)$ per acre of the total cost for CS-I and CS-II respectively. The next important cost item was marketing cost, which was Rs. 3,668.22 and Rs 4,449.76 forming 12.06 and 12.81 per cent of total cost, respectively. The fixed costs (land revenue, rental value of land, depreciation and interest on fixed capital @ 11 percent) accounted for $0.08,3.85,2.24$ and 0.68 per cent of total cost of cultivation for CS-I and 0.07, 3.45, 2.03 and 0.61 per cent in the same order for CS-II (Table 1).

In the case of sole Tobacco farmers, it was observed that the total cost of Tobacco cultivation as sole crop was Rs. 30,423.85 per acre. Total fixed cost formed 6.85 per cent of total cost of cultivation. In the case of farmers cultivating tobacco as an inter-crop with Sorghum, it was observed that the total cost of tobacco cultivation was Rs. 34,731.72 per acre. Total variable cost accounted for 93.84 per cent (Rs. 32,593 per acre) and total fixed cost formed6.16 per cent of total cost of cultivation (Table 1).

The gross return per acre was Rs. 58,904 and Rs. 72,281 for the CS-I and CS-II, respectively (Table 2). Net return in the same order, was Rs. 28,480.15 and Rs. 37,549.28. Returns per rupee of variable cost and returns per rupee of total cost were 2.08 and 1.94 for the sole tobacco farmers and 2.22 and 2.08 for the farmers cultivating tobacco as the inter crop, respectively The economics of intercrop (CS-II) i.e. Tobacco with Sorghum, in terms of yield equivalent clearly demonstrates that, intercropping is more profitable than that of sole crop due to additional returns from the inter crop and better utilization of available resources land, labour capital and management practices.

\section{Resource use efficiency in tobacco production}

In order to maximize the profits from an enterprise, the optimum use of resources is imperative. This is examined based on the productivity of resources used in the production activity. The Cobb-Douglas type 
of production function was used to measure the allocative efficiency of resources under the two cropping systems in the study area. The estimated regression coefficients of various resources used in tobacco sole crop are presented in Table 3.

The coefficient of multiple determination $\left(\mathrm{R}^{2}\right)$ was 0.79 , which indicates that 79 per cent of the variation in gross income was explained by the independent variables included in the production function. From the results, it was observed that the regression coefficients were positive for all the resources except PPC. Fertilizer and machinery hours were statistically significant at five per cent level. Human labour, Animal labour and Seedling cost were statistically significant at one percent level in case of CS-I. The estimated regression coefficients of the resources included in the Tobacco crop for inter crop farmers is presented in the Table 3. It could be observed from the table that, the regression coefficients for all resources used by the farmers were positive.

But variables Farm Yard Manure and Green Manure were only significant at ten per cent level and human labour was significant at five per cent. Fertilizer and Animal labour were significant at one per cent level in case of CSII. This indicates that, by increasing the use of these resources, farmers can increase their net income.

Table.1 Total cost of tobacco cultivation (Rs/ac)

\begin{tabular}{|c|c|c|c|c|c|}
\hline \multirow{2}{*}{$\begin{array}{l}\text { Sl. } \\
\text { No. }\end{array}$} & \multirow[t]{2}{*}{ Particulars } & \multicolumn{2}{|c|}{ Sole } & \multicolumn{2}{|c|}{ Intercrop } \\
\hline & & Value & Per cent share & Value & $\begin{array}{l}\text { Per cent } \\
\text { share }\end{array}$ \\
\hline 1 & Seeds & 1936.96 & 6.37 & 2129.74 & 6.13 \\
\hline 2 & Farm Yard Manure & 371.00 & 1.22 & 507.50 & 1.46 \\
\hline 3 & Fertilizers & 3007.25 & 9.88 & 3019.25 & 8.69 \\
\hline 4 & Green manure & 1507.75 & 4.96 & 1076.75 & 3.10 \\
\hline 5 & Plant protection Chemicals & 528.10 & 1.74 & 796.00 & 2.29 \\
\hline 6 & Labour charges & 15475.50 & 50.87 & 18481.75 & 53.21 \\
\hline 7 & Marketing cost & 3668.22 & 12.06 & 4449.76 & 12.81 \\
\hline 8 & $\begin{array}{l}\text { Interest on working capital } \\
\text { @ } 7 \text { per cent }\end{array}$ & 1845.64 & 6.07 & 2132.25 & 6.14 \\
\hline \multicolumn{2}{|c|}{ Total variable cost (TVC) } & 28340.42 & 93.15 & 32593.00 & 93.84 \\
\hline 1 & Land revenue & 23.24 & 0.08 & 23.68 & 0.07 \\
\hline 2 & Rental value of land & 1172.74 & 3.85 & 1196.53 & 3.45 \\
\hline 3 & Depreciation & 680.98 & 2.24 & 706.56 & 2.03 \\
\hline 4 & $\begin{array}{l}\text { Interest on fixed capital @ } \\
11 \text { percent }\end{array}$ & 206.47 & 0.68 & 211.95 & 0.61 \\
\hline \multicolumn{2}{|c|}{ Total fixed cost (TFC) } & 2083.43 & 6.85 & 2138.72 & 6.16 \\
\hline \multicolumn{2}{|c|}{$\begin{array}{l}\text { Total cost of cultivation (TFC }+ \\
\text { TVC) }\end{array}$} & 30423.85 & 100.00 & 34731.72 & 100.00 \\
\hline
\end{tabular}


Table.2 Returns from tobacco cultivation (Rs/ac)

\begin{tabular}{|c|c|c|c|c|c|c|}
\hline \multirow{3}{*}{$\begin{array}{l}\text { Sl. } \\
\text { No }\end{array}$} & \multirow[t]{3}{*}{ Particulars } & \multicolumn{5}{|c|}{ Farmers } \\
\hline & & \multicolumn{2}{|c|}{ Sole tobacco } & \multicolumn{3}{|c|}{ Tobacco + sorghum } \\
\hline & & $\begin{array}{l}\text { Quantity } \\
\text { (Kg/ac) }\end{array}$ & $\begin{array}{l}\text { Returns } \\
\text { (Rs./ac) }\end{array}$ & $\begin{array}{l}\text { Tobacco } \\
\text { (Kg/ac) }\end{array}$ & $\underset{\text { Sorghum }}{\text { (Kg/ac) }}$ & $\begin{array}{l}\text { Returns } \\
\text { (Rs./ac) }\end{array}$ \\
\hline 1 & $\begin{array}{l}\text { Main product (Kgs/ } \\
\text { ac) }\end{array}$ & 756.54 & 58162.5 & 734.85 & 549.75 & 69236.25 \\
\hline 2 & By-product (Kgs/ ac) & 67.84 & 741.5 & 61.27 & 189.13 & 3044.75 \\
\hline 3 & Gross returns & --- & 58904 & --- & --- & 72281 \\
\hline 4 & Net returns & --- & 28480.15 & --- & --- & 37549.28 \\
\hline 5 & $\begin{array}{l}\text { Net return over total } \\
\text { variable cost }\end{array}$ & --- & 30563.58 & --- & --- & 39688 \\
\hline 6 & $\begin{array}{l}\text { Returns per rupee of } \\
\text { variable cost }\end{array}$ & --- & 2.08 & --- & --- & 2.22 \\
\hline
\end{tabular}

Table.3 Results of Cobb-Douglas function analysis (Dependent variable: Gross return (Rs/ac))

\begin{tabular}{|c|c|c|c|c|c|}
\hline \multirow[t]{2}{*}{ Particulars } & \multirow[t]{2}{*}{ Parameter } & \multicolumn{2}{|c|}{$\begin{array}{l}\text { Sole crop } \\
\text { (CS-I) }\end{array}$} & \multicolumn{2}{|c|}{$\begin{array}{l}\text { Inter crop } \\
\text { (CS-II) }\end{array}$} \\
\hline & & $\begin{array}{c}\text { Output } \\
\text { elasticities }\end{array}$ & $|t|$ & $\begin{array}{c}\text { Output } \\
\text { elasticities }\end{array}$ & $|t|$ \\
\hline Intercept & A & $\begin{array}{r}4.8368 * * \\
(1.8811)\end{array}$ & 2.57 & $\begin{array}{r}7.3057 * * * \\
(1.9176)\end{array}$ & 3.81 \\
\hline \multirow{2}{*}{ Fertilizer (Rs.) } & \multirow[t]{2}{*}{$b_{1}$} & $0.2171 * *$ & \multirow[t]{2}{*}{2.50} & $0.2224 * * *$ & \multirow[t]{2}{*}{4.19} \\
\hline & & $(0.1577)$ & & $(0.106)$ & \\
\hline \multirow[t]{2}{*}{ FYM and GM (Rs.) } & \multirow[t]{2}{*}{$b_{2}$} & 0.0262 & \multirow[t]{2}{*}{0.77} & $0.0312 *$ & \multirow[t]{2}{*}{1.85} \\
\hline & & (0.0109) & & $(0.0276)$ & \\
\hline \multirow[t]{2}{*}{ Human labour (Rs.) } & \multirow[t]{2}{*}{$\mathrm{b}_{3}$} & $0.2107 * * *$ & \multirow[t]{2}{*}{2.70} & $0.2161 * *$ & \multirow[t]{2}{*}{2.59} \\
\hline & & $(0.1411)$ & & $(0.1747)$ & \\
\hline \multirow[t]{2}{*}{ Animal labour (Rs.) } & \multirow[t]{2}{*}{$b_{4}$} & $0.0637 * * *$ & \multirow[t]{2}{*}{4.19} & $0.3824 * * *$ & \multirow[t]{2}{*}{3.52} \\
\hline & & $(0.0256)$ & & $(0.1944)$ & \\
\hline \multirow{2}{*}{$\begin{array}{l}\text { Machinery hours } \\
\text { (Rs.) }\end{array}$} & \multirow[t]{2}{*}{$\mathrm{b}_{5}$} & $0.0114 * *$ & \multirow[t]{2}{*}{2.05} & 0.0562 & \multirow[t]{2}{*}{0.81} \\
\hline & & $(0.0091)$ & & $(0.0693)$ & \\
\hline \multirow[t]{2}{*}{ Seedling cost (Rs.) } & \multirow[t]{2}{*}{$b_{6}$} & $0.4929 * * *$ & \multirow[t]{2}{*}{4.31} & 0.0907 & \multirow[t]{2}{*}{0.96} \\
\hline & & $(0.2146)$ & & $(0.1471)$ & \\
\hline \multirow[t]{5}{*}{ PPC (Rs.) } & \multirow[t]{2}{*}{$\mathrm{b}_{7}$} & 0.0411 & \multirow[t]{2}{*}{0.57} & 0.0189 & \multirow[t]{2}{*}{1.37} \\
\hline & & $(0.0388)$ & & $(0.0233)$ & \\
\hline & $\begin{array}{l}\text { Returns to } \\
\text { Scale }\left(\sum \text { bi) }\right.\end{array}$ & 1.06 & --- & 1.02 & --- \\
\hline & $\mathbf{R}^{2}$ & 0.79 & --- & 0.77 & --- \\
\hline & Adjusted $\mathbf{R}^{2}$ & 0.73 & --- & 0.73 & --- \\
\hline
\end{tabular}

Note: Figures in parentheses indicate standard errors

$* * *, * *$ and $*$ Significant at one, five and ten percent level respectively.

CS-I: Sole Tobacco

CS-II: Tobacco + sorghum 
Table.4 MVP to MFC ratios of resources in tobacco production

\begin{tabular}{|c|c|c|c|c|c|c|c|}
\hline \multirow{2}{*}{$\begin{array}{l}\text { Sl. } \\
\text { No }\end{array}$} & \multirow[t]{2}{*}{ Variables } & \multicolumn{3}{|c|}{ Sole tobacco } & \multicolumn{3}{|c|}{ Tobacco as intercrop } \\
\hline & & MVP & MFC & Ratio & MVP & MFC & Ratio \\
\hline 1. & Fertilizer (Rs.) & 3.67 & 1 & 3.67 & 5.44 & 1 & 5.44 \\
\hline 2. & FYM and GM (Rs.) & --- & --- & --- & 1.25 & 1 & 1.25 \\
\hline 3. & Human labour (Rs) & 1.68 & 1 & 1.68 & 1.80 & 1 & 1.80 \\
\hline 4. & Animal labour (Rs.) & 7.77 & 1 & 7.77 & 10.43 & 1 & 10.43 \\
\hline 5. & Machine hours (Rs.) & 0.52 & 1 & 0.52 & --- & --- & --- \\
\hline 6. & Seedling (Rs.) & 9.81 & 1 & 9.81 & --- & --- & --- \\
\hline
\end{tabular}

\section{Allocative efficiency in Tobacco production}

As it could be observed from the Table 4 that, for sole tobacco farms, the ratio of Marginal Value Product (MVP) to Marginal Factor Cost (MFC) was greater than unity for the resources like fertilizer (3.67), Human labour (1.68), animal labour (7.77) and seedling (9.81) indicating these resources were sub-optimally used in Tobacco production, while machinery hours (0.52) was less than unity, indicating over use of this resource in tobacco.

In case tobacco and sorghum inter crop farms, the MVP to MFC ratio was greater than unity for fertilizer (5.44), FYM and GM (1.25) and human labour (10.43) indicating these resources were sub-optimally used in tobacco production, which indicates that there was still scope for increasing use of these resources to get increased returns.

In conclusion the critically reviewing the above results, it is found that, the total cost of cultivation was higher in CS-II as compared to CS-I and intercropping was more profitable than that of sole crop. Hence, efforts should be made to encourage farmers to adopt intercropping system to enhance their income which will also avoid the risk of crop failure. In CS-I the MVP to MFC ratios were found to be greater than one for all the resources except for machinery hours and in CS-II it was greater than unity for fertilizer, FYM and GM, human labour and animal labour indicating that these resources were used below their optimum level. Therefore it is necessary to educate the farmers to use resource optimally so that the profits can be maximized and at the same time the wastage of the resources can be avoided.

\section{References}

Doshi, R.R., 1985. Processing and marketing of beedi tobacco in Nipani tract. Ph.D. thesis (Unpub.) submitted to Poona University, Poona.

Government of India, 2019a. Tobacco Board, Ministry of Commerce and Industries.

Government of India, 2019b. Department of Agriculture and Cooperation, Directorate of Economics, \& Statistics, Agricultural Statistics at a Glance 2019, New Delhi.

Government of Karnataka, 2009. District Statistical Office, Belgaum, Karnataka.

Rajesh, T. and Ananth G. S. 2012. Study of production and marketing of Tobacco in Belgaum district of Karnataka-An economic analysis, M.Sc. Thesis, University of Agricultural Sciences, Bengaluru.

\section{How to cite this article:}

Rajesh, T. and Ananth, G. S. 2020. An Economic Analysis of Bidi Tobacco Cultivation in Belgaum District, Karnataka. Int.J.Curr.Microbiol.App.Sci. 9(12): 526-531. doi: https://doi.org/10.20546/ijcmas.2020.912.062 